\title{
The Dilemma of Basia's Pendant: European Community Design and the Protection of an Artist's Creations and Intellectual Property
}

\author{
Richard J. Hunter, Jr. \\ Hector R. Lozada \\ John H. Shannon \\ Seton Hall University
}

USA

And

Barbara Cetrangolo Rivolta

Technical and Artistic Consultant

A R T I C L E I N F O
Article history: Research
Received : 20 December 2020
Revised : 31 December 2020
Accepted: 1 January 2021
DOI: 10.47742/ijbssr.v2n1p1

\begin{abstract}
A B S T R A C T
This article is a description of the process of protecting a designer's intellectual property through registration with the European Union Intellectual Property Office or EUIPO or through relying on the status of an Unregistered Community Design. The article discusses the registration process as well as the process of invalidation and considers issues relating to the enforcement of rights. Finally, the article focuses on whether a complaint about possible copyright infringement may be lodged against an online retailer or an online e-commerce website that offers unlicensed sales or unauthorized copies of a designer's design by utilizing the descriptions or photographs of the designer.
\end{abstract}

Keywords: Community design, infringements, registration, invalidation, copyright, registered community design, EUIPO

\section{Statement of the Problem}

Consider this scenario:

Basia Rykowska is a jewelry designer based in Poznan, Poland, who also sells jewelry to buyers in Slovakia and Germany. Recently, Basia began to advertise on ETSY, "an American e-commerce website focused on hand made or vintage items." Basia created a new jewelry design in the form of a pendant which she calls "The Stag." She wants to protect her creation and avoid the possibility that one or more of her competitors may copy her design or even worse, create a cheap imitation that might significantly impact her brand so Basia decides to take steps to protect her design with the European Union Intellectual Property Office(EUIPO). She becomes especially concerned when she comes across similar designs, but of much lower quality, being sold on eBay and Alibaba for a fraction of the selling price of her jewelry (see Tse, 2016). In some cases, the eBay and Alibaba sellers are using her exact written descriptions of her pieces and even the photographs of her originally designed jewelry to depict their lower quality jewelry.

Although Basia has learned that her new creation can be protected for free (as an Unregistered Community Design), she also discovers the limitations to this type of protection: the protection as an unregistered community design only covers deliberate copying of the pendant, but not the independent development of a similar design. Basia has spent a lot of time creating the pendant (as well as her entire collection). She thinks that it is going to be a very successful product line. Basia has decided to protect her creation with a Registered Community Design, which costs EUR 350 and lasts five years, with possible renewals every five years, for up to 25 years.

However, there are several questions remaining: Even if Basia is successful in registering her design or in asserting the protections of an Unregistered Community Design, will she be able to seek a remedy against the person or persons whom she believes are infringing on her rights? If Basia is unsuccessful in asserting her design rights, may she nevertheless proceed against any party or parties who have copied her descriptive texts or the photographs of her jewelry or the e-commerce websites where the text or photographs have appeared? Are these issues further complicated because one of the alleged infringing parties, Alibaba, is located in China, which is a non-signatory to The Hague Agreement Concerning the International Registration of Industrial Designs (WIPO, 2020a), but is a signatory to the Berne Convention for the Protection of Literary and Artistic Works? *

\section{PART I-DESIGN PATENTS IN THE EUROPEAN UNION}

\section{The EUIPO: A Brief Discussion}

The European Union Intellectual Property Office, known as EUIPO (see Sfarlog, 2020), manages trademark and design rights in the European Union, the European Observatory on Infringements of Intellectual Property Rights (EUIPO, 2020a), 
and the Orphan Works Database (EUIPO, 2020b). The European Observatory on Infringements of Intellectual Property Rights is a "network of experts and specialist stakeholders. The Observatory's objectives are to provide evidence-based contributions and data to enable EU policymakers to shape effective IP enforcement policies and to support innovation and creativity" (EUIPO, 2020a).

\section{According to EUIPO (2020b),}

"Orphan works are works that are still protected by copyright, but whose authors or other right holders are not known or cannot be located. Music, books, newspaper and magazine articles, and films can be orphans. Orphan works are part of the collections currently held by European libraries, museums, archives, film and audio heritage institutions, and public service broadcasting organizations. The lack of data on their ownership has often constituted an obstacle to their digitization and making them available online. The rights administered by the EUIPO complement national intellectual property (IP) rights and are linked to international IP systems.',

EUIPO was established in 1994. Its current Executive Director is Christian Archambeau, who has held this position since 2019. EUIPO is headquartered in Alicante (Spain). EUIPO receives and examines over 150,000 trademark and 90,000 design applications each year. Lince (2020) reports that "from 2010 to 2017, more than 956,000 EU trademark applications were filed at the EUIPO, with an average annual growth rate of $5.9 \%$ and overall growth of almost 49\%. As of 1 January 2018, there were more than 1.2 million EU trademark registrations containing nearly 3.4 million associated goods and services classes." EUIPO is a decentralized agency of the European Union, cooperating closely with the European Commission and its Directorate-General for Internal Market, Industry, Entrepreneurship and SMEs. EUIPO is governed by a Management Board and Budget Committee, comprised of:

- 1 representative per EU country;

- 1 representative from the European Parliament; and

- 2 representatives from the European Commission. EUIPO also works closely with the European Patent Office (EPO) (Nieto et al., 2015; European Patent Office; 2020) and the World Intellectual Property Organization (WIPO) (2013) to raise awareness of intellectual property rights protection.

The European design patent may be obtained in a simple registration procedure by means of a single application that it is uniformly valid in the twenty-seven member states of the European Union (Cremers et al., 2016) which include: Austria, Belgium, Bulgaria, Croatia, Republic of Cyprus, Czech Republic, Denmark, Estonia, Finland, France, Germany, Greece, Hungary, Ireland, Italy, Latvia, Lithuania, Luxembourg, Malta, Netherlands, Poland, Portugal, Romania, Slovakia, Slovenia, Spain, and Sweden.

\section{Community Designs in the European Union}

A European design patent also referred to as a Community Design, is "an exclusive right which protects the two- or three-dimensional aesthetic design of a product, resulting from its visible features, in particular, the lines, contours, colors, shape, texture and/or materials" (see Afori, 2008; Kasperkiewicz, 2017). There are two types of protections: a Registered Community Design or RCD and an Unregistered Community Design or UCD. Community Designs have a unitary character, which implies that they have an equal effect throughout the European Union.

A holder of a Registered Community Design (RCD) has the exclusive right to use the design and to prevent any third party from using it anywhere within the European Union without the permission of the holder (see Heneghan, 2015). The rights of the holder extend to making, offering, marketing, licensing, importing, exporting, or using a product in which the design is incorporated or to which it is applied. The RCD protects against both imitations (commonly referred to as "knockoffs" in the United States) and the development of an identical or similar design by third parties (Woods \& Monroig, 2015; Graneris, 2018; Wu, 2019; Huang \& Li, 2019). Martinez (2019, p. 380) notes that "Registration of a design with the European Union Intellectual Property Office (EUIPO) grants the designer a monopoly for all original designs and is renewable every five years for up to years for up to twenty-five years from the date of filing" (see also Monseau, 2011). By way of contrast, Kasperkiewicz (2017) notes that an "unregistered right (described in detail below) gives protection against deliberate copying of a design for a period up to three years, from the date the design was first made available to the public within the territory of the European Union."

The registered illustrations, depictions, or descriptions of the product put forth by the putative holder will determine the level of protection. As a result, the protection only refers to the visible features of the registered illustration. An applicant should understand that it is critical to file appropriate illustrations with the European Design Patent Office. Failure to do so may result in the inability of a designer to fully enforce rights against a competitor or an alleged infringer.

\section{Registration}

The key to protection as an RCD lies in the registration process. Any two-dimensional or three-dimensional appearance of a product, or of a part of it, can be protected. A product can be defined as any "industrial or handicraft item, including packaging [sometimes referred to as "trade dress" in the United States], equipment, graphic symbols and typographic characters and items that can be assembled into a complex product" (Patworx, 2020). Thinn Oo (2019, p. 268) notes: "Trade dress encompasses the total image and impression created by a product. Trade dress infringement occurs when one company uses trade dress similar enough to another's to cause a "likelihood of confusion" in an ordinary buyer's mind" (see also Ramirez-Montes, 2020).

The definition of a product is similar to that which appears in the discussion of product liability in the United States (Lannetti, 2000). According to the Model Uniform Product 
Liability Act (Section 102(c)) (see Jobe, 1981), a product includes "all goods, wares, merchandise, and their components, as well as articles and commodities capable of delivery for introduction into trade or commerce." However, a computer program is not considered as a product in the EU (see Ganim, 2019/2020), but may be subject to copyright. The design of a product must not be based on the technical function or the purpose of the use of a product. As a result, designs that are dictated exclusively by the technical function of a product cannot be protected.

There are two major requirements for registration: A design can only be protected, and thus registered when the design is new and has individual character (Conea, 2011; Leitch, 2018). A design is considered to be new if no identical design has been made available to the public. This standard is similar to that referenced to patents in the United States. The web site of the law firm of Tsyver Beck Evans (2020) notes that in the United States, "an invention will not normally be patentable if:

- the invention was known to the public before the applicant filed for patent protection;

- the invention was described in a printed publication before the applicant filed for patent protection; or

- the invention was described in a published patent application or issued patent that was filed before the applicant filed for patent protection."

By way of comparison, under Article 6 of the Community Design Regulation, a design has individual character if the "overall impression it produces on the informed user differs from the overall impression produced on such a user by any design which has been made available to the public" (see also Ling, 2019). The overall impression only needs to be slightly different from that of any existing design. A "special" or "unique" creative achievement is not required.

Community Design applications are to be filed directly with the EUIPO. One important requirement is that the individual designs all belong to the same product class. However, as Kielar (2020, p. 1208) notes: "A single registered community design application may include an unlimited number of designs, and the designs do not need to be related to one another. The only requirement is that each design falls within one of the 32 Locarno classes. The subclasses of each design, however, may be different. This requirement is referred to as the 'unity of the class.' An application may be divided, i.e. restricted, if the designs fail to have unity of the class." In the case of an online filing of multiple applications, there is an upper limit of 99 designs.

The Locarno Classification was the product of an international conference to which all the countries that were signatories to the Paris Convention for the Protection of Industrial Property were invited. The conference was held in Locarno (Switzerland). The Locarno Agreement was adopted on October 8, 1968, establishing an International Classification for Industrial Designs (WIPO, 2020b; see also generally Morris, 2019). The Locarno Classification comprises:

- a list of classes and subclasses;
- an alphabetical list of goods which constitute industrial designs, with an indication of the classes and subclasses into which they fall;

- $\quad$ explanatory notes (WIPO, 2020).

An application will be assessed only about its formal requirements. There is no substantive examination of the novelty and individual character requirements. The application will be assessed only as to whether it relates to a design in general and whether the design is "contrary to public policy or is contrary to accepted principles of morality" (see, e.g., Davis, 2020). If the application does not meet the formal requirements, the EUIPO will issue an official communication, including an objection to its registration. This is usually done using a "deficiency notice" in which the applicant is given a deadline to respond to the notice to correct any deficiency.

Interestingly, a design may be registered even if the design is not new and has no individual character. However, in this case, the registration does not have any legal effect but is only considered as a "pseudo registration" (Patworx, 2020) from which no rights can be derived. The validity of the design patent may not be determined until "litigation proceedings, cancellation proceedings, or revocation proceedings" have taken place, in which case, "the holder of a design registration takes a significant risk if the design is not valid" (Patworx, 2020).

\section{An Unregistered Community Design}

The second type of Community Design is an Unregistered Community Design or UCD. The UCD is very similar to a Registered Community Design (see Fanelli, 2011), but an Unregistered Community Design is given protection for only three years from the date on which the design was first made available to the public within the territory of the European Union. Both registered and unregistered community designs have to meet the same conditions to be protected that is, they must be both new and must have individual character. The provisions relating to the unregistered right came into effect on March 6, 2002.

Unlike a Registered Community Design, the holder of an Unregistered Community Design is not required to apply to receive protection. An unregistered right gives protection against deliberate copying of design for a period of up to three years (see Kropiwnicka, 2019). The RCD in contrast protects against both imitations and the development of an identical or similar design by third parties.

During the 12 months after the first disclosure of the design, the designer may apply for a Registered Community Design to increase the level of protection. As a result of the dual system of protection, all new and original designs now automatically receive at least a minimum form of protection. The unregistered design is not granted a monopoly or exclusivity, but it prevents the actual copying of the design.

In sum, the critical differences between registered and unregistered designs are based on the validity period (a possible 25 years, versus 3 years); the Registered Community Design is granted protection against a similar design, and the holder of an 
https://ijbssrnet.com/index.php/ijbssr DOI: 10.47742/ijbssr.v2n1p1

RCD obtains a certificate which makes easier to prove the ownership in any potential dispute.

\section{Disputes (EUIPO, 2020b)}

The owner of a Registered Community Design can "challenge" potentially conflicting rights (see Mudrytska, 2020); however, the validity of the RCD itself can also be "challenged" or "attacked." These challenges can take place at different levels - either before the European Union Intellectual Property Office or before national courts of EU member states.

Unlike the situation relating to trademarks, where disputes can arise before registration of the trademark, designs can be challenged only after they are registered. This challenge is termed as "an application for a declaration of invalidity" (see Bulling, Langohrig, \&Hellwig, 2004).

\subsection{Reasons for Invalidation}

Article 25(1)(b) of the Community Design Regulation sets out the grounds that can be invoked in seeking a declaration of invalidity. The most frequent grounds are that the design is not new or does not possess an individual character. Ironically, the party seeking a declaration of invalidity does not need to own or possess an earlier right to file such a request. The challenging party, however, is required to show that the same design or a similar one existed before the design against which the invalidity request is directed. As a matter of proof, the challenging party has the burden of showing that:

- That an earlier design has been "disclosed" or was in existence;

- That the two designs make the same overall impression on the informed user (see, e.g., Miniotas, 2005). In this case, the price of an item may be an important-if not critical-factor.

As to the issue of an "informed user," Baudhuin (2015) commented:

"Courts have also addressed the meaning of "informed." The court in Woodhouse UK Plc v. Architectural Lighting Systems (2006) held that a user who is informed has "a notion of familiarity with the relevant rather more than what one might expect of the average consumer," a user who asks: ""what's about in the market?' and "what has been about in the recent past?" This does not require that a user have an "archival mind" that can recall explicit details regarding all related products, but it does require some "basic awareness of product trend ... and some knowledge of basic technological considerations (if any)."'”

A representation of the prior design(s), supported by documentary evidence of disclosure, is required. For example:

- “Official publications: publication of an earlier design in the bulletin of any IP office anywhere in the world generally constitutes disclosure, as can publications in trademark and patent bulletins.

- Exhibitions and use in trade: making a design available to the public at an international exhibition anywhere in the world generally constitutes disclosure, as can use in trade.

- Disclosures on the internet: as a matter of principle, disclosures on the internet form part of the prior art. Information disclosed on the internet or in online databases is considered to be publicly available as of the date the information was posted. However, the nature of the internet can make it difficult to establish the actual date on which information was made available to the public: not all web pages' mention when they were published.

- Statements in writing, sworn or affirmed (affidavits): as a matter of principle, affidavits in themselves are not sufficient for proving the disclosure of an earlier design. They can, however, corroborate and/or clarify the accuracy of other documents.

- The overall impression on the informed user."

When comparing two designs to determine the issue of invalidity, EUIPO will apply the same criteria as it would normally apply when it searches determining any earlier rights relating to registration; that is, EUIPO will consider issues of novelty and individual character at this point.

\subsection{The Invalidity Process}

The fee for the application for a declaration of invalidity is EURO 350. Applications for invalidity will not be considered filed until the fee has been paid in full. What are the steps in the invalidity process?

"EUIPO will inform the RCD owner that an application for a declaration of invalidity has been filed and will give the RCD owner two months to reply. If the RCD owner decides not to reply, EUIPO makes a decision based on the application as filed by the invalidity applicant. If the $R C D$ owner decides to reply, their comments are communicated to the invalidity applicant immediately. If EUIPO determines that there is sufficient information to render a decision, it does so. If not, a further round of correspondence might be exchanged."

"Either party can ask for an extension of time if the twomonth period is not sufficient. As a general rule, the first request for extension of this period is granted automatically. Further extensions are granted only if sufficiently and properly justified" (EUIPO, 2020c).

\section{Enforcement}

Since community designs have both a "unitary character" and "equal effect throughout the Community," the law firm of Bardehle Pagenberg (2020) notes that it is "established case law that a claim for cease-and-desist (injunctive relief) on the grounds of a Community design infringement applies, as a rule, to the entire territory of the EU, because an infringement committed anywhere in the European Union establishes, in principle, a risk of repeat infringement for the entire territory of the EU" (see also Krikke \& Klopper, 2020). Further, "Remedies in cases of design infringement are in practice primarily civil remedies (injunction, damages, etc.), although penal remedies exist as well, as do 
administrative remedies such as border seizures" (see also Bonadio, 2007; Zelechowski, 2016).

Bulling, Langohrig, and Hellwig (2004, p. 133) point out that "A Community Design Court can impose the following sanctions for infringement, or threatened infringement, as set out in Art. 89, para. 1 (a-d):

- an order enjoining infringing acts;

- an order to seize infringing products;

- an order to seize materials and/or implements used predominantly to manufacture infringing goods, if the owner knows or should have known of the infringement; - an order imposing other sanctions (e.g., monetary damages), as provided by the law of the Member State in which the infringing acts were committed or threatened."

Sciaudone (2012, p. 401) noted that the Court of Justice of the European Union (ECJ) (Zhang, 2016; Keleman, 2016; Kuijper, 2018; has clarified that the holder of a Registered Community Design is "entitled to bring enforcement proceedings against any third party, including the holder of a later community design registration, without having first to request the declaration of invalidity; in this respect, the intention or conduct of a third party is irrelevant."

\section{Moving Forward}

The website Up Counsel (2020) notes that "Design patent infringement occurs when a company or person violates a design patent's terms. A design patent protects a manufactured product's ornamental features. To claim infringement, you must prove that an ordinary observer wouldn't be able to tell the difference between a patented object's design and an accused object's design when both designs are side by side." The test in the case of "Basia's Pendant" involves the concept of an "Ordinary Observer," which looks at whether an ordinary person (not someone who is a design expert) can see a definite similarity in the designs of two objects. Up Counsel (2020) proposes the following test:

"Think of someone standing in a store [or in this case, viewing the items on the internet] trying to decide between two items to buy. If that person can't tell a difference when looking only at the outside design, you may have a case for design patent infringement based on substantial similarity."

In this case, however, the overall lack of specificity and detail, and the overall dissimilarity of the design even to the casual observer, as well as the substantial disparity in price between the items, might make it exceedingly difficult for Basia to make out a successful claim for a design patent infringement.

Interestingly, Basia might turn her dilemma into a positive: Basia should stress in her descriptive advertising that her works are of distinctive, high, and exceptional quality sometimes referred to as "heirloom quality" and should not be confused with the lower quality pendants and jewelry found elsewhere on the web. Basis should take note that Kennedy (2014) has stated that "The word heirloom is defined as, a "valuable object that has belonged to a family for several generations.' What makes a piece of jewelry an heirloom? Value, quality, and beauty are all important factors. For me, it's the stories behind the piece. There are stories of love, dreams, accomplishments, and sometimes even loss." Telling these "stories" in her descriptions (and depicted in her photographs) should be the focus of her attention in the future if Basia wishes to maintain her distinctiveness on the world market.

But, that does not mean that Basia is complete without a remedy.

\section{PART II-COPYRIGHT INFRINGEMENT IN EUROPEAN UNION: WILL IT PROTECT BASIA? \\ 9. Copyright Infringement}

A second issue relating to "Basia's Pendant Dilemma" centers around the use of her design descriptions and even the photographs of her designs which she has posted on ETSY or her web pages.

The European IPR Helpdesk (European Union, 2020) defines copyright as:

"an intellectual property right (IPR) that grants authors, artists and other creators protection for their literary, artistic and scientific creations, generally referred to as 'works.' Giving authors, artists and other creators incentives in the form of recognition and a potential fair economic reward allows them to concentrate on the creative part of their activity - literary and artistic creation. This, in turn, helps to increase access to and enhance the enjoyment of culture, knowledge, and entertainment the world over."

Common examples of copyrighted works include books, musical compositions, or movies. "Copyright can also protect a website, a brochure, a corporate video, newspapers, periodicals, printing, advertising, radio, and television broadcasting, sound recording, musical and audiovisual works, motion pictures, and computer software" [emphasis added] (European Union, 2020).

Copyright arises automatically when the work has created the creator of a work is not required to register or to undertake any other actions to enjoy the benefits of copyright protection. However, it is a common practice to attach a copyright notice to the work to inform others of the existence of copyright, reduce the likelihood of a potential infringement. This notice includes the mention "all rights reserved" or the symbol C together with the year in which the work has been created, e.g.: (C) European Union (2020), (C) 2020 Copyright holder. All rights reserved.

In this regard, the Berne Convention is especially relevant. The Berne Convention is a treaty for the protection of literary and artistic works, signed by nearly 180 countries (Burger, 1988; Ricketson \& Ginsburg, 2006). Other relevant treaties and conventions include the various World Intellectual Property Organization (WIPO) treaties, the Rome Convention of 1961 (see Davies, 2012), The Hague Agreement Concerning the International Registration of Industrial Designs (WIPO, 2020a), and the Agreement on Trade-Related Aspects of Intellectual Property Rights, more commonly known as the TRIPS Agreement (Yu, 2020). Copyright law is not fully harmonized at 
the EU and international levels, therefore the national laws of the country in which the author seeks protection apply. However, in all cases, for works to be protected by copyright they must be original. According to the EUIPO website "FAQs on Copyright" (EUIPO, 2020d), "Copyright implies the exclusive right to control a work by reproducing it and making it available to the public...."

At the international level, minimum standards of protection have been established by the Berne Convention and are based on three basic principles:

- National treatment: works are given the same protection in each country as the country grants to the works of their nationals.

- Automatic protection: no formalities required.

- Independence of protection: works receive protection even if they cannot obtain such protection in their country of origin.

\subsubsection{Photographic Protections}

As a general rule, commercial use or exploitation of copyrighted materials requires a license or an assignment of rights from the rights owner. Would copyright protection also apply to a photograph posted by the designer?

EU Directive 2006/116/EC states: "Photographs which are original in the sense that they are the author's intellectual creation shall be protected" and "Member states may provide for the protection of other photographs" (see PhotoClaim, 2020). According to Zhang (2018), online photos cannot be used without permission, citing Land Nordrhein-Westfalen v. Dirk Renckoff, a case decided by the Court of Justice of the European Union in August of 2018 (see also Saw, 2018).

EUIPO (2020d) adds, however, "The photograph is only protected if the photographer has made creative choices. This means that the photographer has to have considered such issues as background, the subject's pose, the lighting, the framing, the angle of the view and the atmosphere created" (see also Hughes, 2012; Silbey, 2019; Silbey, Subotnik, \& DiCola, 2019). PhotoClaim (2020) notes further that "everywhere in Europe you can expect your photo to be copyrighted as long as it's your intellectual creation. What is an intellectual creation? You may ask. This question is not easy to answer. If you can show that you had some thoughts about composition, the use of light, special techniques, creative techniques, creative ideas, etc. your artwork should be protected."

The use of a description or a photograph available on the Internet would likewise require the prior authorization of the copyright owner. "That applies to pictures, marketing videos, clips, articles published in newspapers, corporate brochures, website design, etc. The mere fact that a work is available digitally does not mean copyright law does not protect it. Downloading content from any website is making a copy of that content, which can be compared to making copies of a book in a library. Such action may therefore constitute a copyright infringement" (European Union, 2020). Zhang (2018) offers a cogent summary: "Any use of a work by a third party without such prior consent must be regarded as infringing the rights copyright of that work" (citing Land Nordrhein-Westfalen v. Dirk Renckhoff, 2018).

\subsubsection{Remedies: But Are They Realistic?}

It is standard procedure to start with sending a cease and desist letter before resorting to the judicial system to enforce a copyright. "A cease and desist letter is a notification stating the allegations of infringement and demanding that such infringement stops" (see, e.g., Gallagher, 2012). If a "cease" letter fails to achieve its purpose, alternative methods of solving disputes such as mediation or arbitration may be available.

Many of Basia's complaints stem from the sale of jewelry and pendants on eBay or on the Chinese website Alibaba (see Chow, 2020). One complication is that Alibaba is a Chinese multinational technology company specializing in e-commerce, retail, Internet, and technology. It was founded in 1999 in Hangzhou, China, by Jack Ma and his team of seventeen friends. Alibaba is the world's largest retailer and e-commerce company. The web site of Alibaba provides the opportunity to complain of copyright infringement (see Appendix I) against one of its sellers. This is quite ironic since, according to Zongiu (2015, quoted in Huang, 2015),

"Alibaba Group, for a long time, has failed to take seriously the operational violations on its e-commerce platforms and did not take effective measures to address the violations. This caused a miniscule issue to snowball into a serious problem, leading Alibaba to its greatest crisis since its incorporation. This critique is not directed at practices involving IP rights; it is directed at an underlying culture at Alibaba, which is one of viewing itself as above the law, including an attitude of a willful refusal to obey the law. At another point, the SAIC White Paper states: 'It is suspected that Alibaba knowingly, intentionally, by negligence or despite their presumed knowledge facilitates unlicensed operations, trademark infringement, untruthful publicity, pyramid schemes and violations of consumer rights.",

Although more complicated because of jurisdictional or service of process issues, in the case of a failure to reach an amicable solution to a complaint relating to possible copyright infringement, the holder of a copyright can also ask a court to issue an injunction, which is an order to prohibit the infringer from using the copyrighted work. Copyright holders whose rights have been infringed can also seek damages, for example, in a form of a monetary payment, for any loss they may have incurred as a result of the infringement. The purpose of damages is, therefore, to restore the copyright holders to the position in which they would have been if the infringement had not occurred.

However, in the case of "Basia's Pendant," one of the alleged primary infringers (Alibaba) is a Chinese company. China is not a member of the European Union and is also not a signatory to The Hague Agreement relating to industrial designs, although the law firm of Schmitt and Orlov (2019) notes, "China 
has made the first steps in protecting designs under The Hague Agreement."

At the same time, China is a signatory to the Berne Convention relating to copyrights. This dichotomy makes seeking a judicial remedy against one or more of the infringing parties quite problematic. Under these circumstances, it may be more realistic to take action against a company such as eBay, as it is an American company with headquarters in San Jose, California, or a company that imports Chinese products into the United States with a California mailing address. In contrast to China, the United States is a signatory to both The Hague Agreement and the Berne Convention.

10. Conclusions, Observations, and Suggested Actions

It is certainly true that Basia is already protected from design infringement as an Unregistered Community Design in the European Union. Also, to afford her maximum protection from copying, at least within the European Union, or in countries which are signatories to The Hague Agreement, Basia should consider registering her design, and eventually all of her designs, as a Registered Community Design. Her work certainly meets the dual criteria of novelty and individual character.

However, if an "informed user" were to carefully compare Exemplar 1 and Exemplar 2 as to their visible features and price, it might be difficult to prove that the design on eBay had infringed on Basia's design. But that is not the end of the story!

What has occurred, as demonstrated by Exemplar 4, is that the seller or sellers on the AliExpress.com web site appropriated Basia's photograph (and possible description) to advertise their design. To be sure, Basia's photographs are already subject to copyright and the unauthorized duplication of these photographs would amount to copyright infringement. In the future, not only should Basia be careful to include an identifying watermark on the photographs, but she should also be sure to include an appropriate notice with the photograph and any description or titles of the works such as (C) European Union 2021. All Rights Reserved.

Basia (or her representative) should contact both eBay and Alibaba, as well as any other internet sites or American companies that are selling these items, and demand that they immediately "cease" from any offerings on their sites that include any descriptions or photographs of her designs.

\subsection{One More Thing...}

As we have mentioned earlier, the Berne Convention protects the copyright of authors of artistic and literary works including their photographs and descriptions. The main intention is to provide these creators with means to control how their works are used, by whom, and upon what terms. Under the Agreement on Trade-Related Aspects of Intellectual Property Rights (TRIPS), the principles of national treatment, automatic protection, and independence of protection also bind those World Trade Organization members not a party to the Berne Convention. These treaties and international regimes allow the holder of a copyright to protect his/her rights abroad. For MNCs and other large corporations, this seems fairly straightforward.

However, for small- and medium-sized businesses, or individual artists or entrepreneurs, it becomes a practical question relating to how much time, effort, and money would be required to resolve all the issues involved. International litigation can be expensive and more complicated than domestic litigation (see, e.g., Association of Corporate Counsel, 2019). And then, there is the issue of enforcement: even if you win a case of copyright infringement, how do you monitor and assure compliance when resources are limited? Will a win in court be worth the money and effort? A copyright violation is both an economic and a moral transgression, but sometimes pursuing infringers will result in wasted time and effort. Sadly, infringers usually count on this flaw on the enforcement side.

In the particular case of China, we must note that not only is China a member of the WTO, and therefore TRIPS, but China became a signatory of the Berne Convention in 1992. Still, it is unclear how individual artists or creators could find remedies when copyright infringement by a Chinese party occurs. From our standpoint, this only enhances the importance of engaging China not only in multilateral agreements but also in continuously pointing out when the behavior of their citizens and companies results in the violation of the economic and artistic rights of others. Being a part of a global economy and the global community must require all participants to observe the agreedupon rules. Tariffs alone will not solve these problems.

\section{* AUTHORS' NOTE}

This study is based on the actual "dilemma" faced by Polish jewelry designer, Anna Mazon, who experienced the copying of her descriptions and photographs by several sellers on both eBay and Alibaba, in addition to offering low-price imitation "knockoffs." We are grateful for the cooperation of Ms. Mazon, as well as the technical and artistic support of co-author Barbara Cetrangolo Rivolta, also a noted jewelry designer and potter, who was our intermediary with Ms. Mazon.

We have provided several exemplars of works, including:

- Exemplar 1: The photographic advertisement of "The Light Bringer" from the website of Anna Mazon and Drakonaria.com, which appeared on ETSY.

- Exemplar 2: The advertisement of "Deer Face" from the eBay website. 


\section{APPENDIX I}

\section{FROM THE ALIBABA INTELLECTUAL PROPERTY PROTECTION PLATFORM}

\section{Before Complaint Submission}

1. How to register/create an account on Intellectual Property Protection Platform (IPP platform)?

2. What is the difference between registered email address and contact email address?

3. Why do some product URLs remain to be valid online after complaint has been processed?

4. Which websites can I submit the IPR complaint against?

\section{Complaint Submission in Progress}

1. Do I need to submit IPR information for authentication before submitting the complaint?

2. I have several IPRs, may I submit all of them together?

3. Why do I need to upload the identification proof?

4. Why do I need to match the IPR information?

5. How to download the authorization letter?

6. After IPR complaint is submitted, how will Alibaba process the complaint?

7. May I provide the Official Filing Receipt issued by intellectual property office as proof of IPR ownership?

8. After I [have] submitted my IPR information, how long can it be authenticated?

9. Why [was] my IPR authentication was withdrawn?

\section{After Complaint Submission}

1 . Why was my IPR complaint rejected to be processed?

2. How to raise the success rate to pass the complaint verification?

3. Why the product listings cannot be submitted successfully?

4. It takes quite a long time to apply Patent Evaluation Report, how to make up for the loss during the application period?

5. [The seller] was not authorized to sell our products and they were selling counterfeit products, why couldn't Alibaba protect our IPR?

6. When I submit complaints, why did I need to confirm the IPP account is the sole account that I will use to file complaint on IPP platform?

7. I am the complainant; how can I follow up the status of my complaint after submission?

\section{REFERENCES}

Afori, O.F. (2008). Reconceptualizing property in designs. Cardozo Arts and Entertainment Law Journal, 25: 1105-1178.

Baudhuin, D.E. (2015). 'Ordinary observer' test for design patent litigation in the United States in response to the Apple v. Samsung disputes. Wisconsin International Law Journal, 33: 290-317.

Bonadio, E. (2007). Remedies and sanctions for the infringement of intellectual property under EC law. European Intellectual Property Review, 30(8): 320-327.

Bulling, A., Langohrig, A., \& Hellwig, T. (2004). The community design: A new right of design protection for the European Community. Journal of Patent and Trademark Office Society, 86: 111-133.

Burger, P. (1988). The Berne Convention: Its history and its key role in the future. Journal of Law and Technology, 3: 1-69.

Chow, D.C.K. (2020). Alibaba, Amazon, and counterfeiting in the age of the Internet. Northwestern Journal of International Law and Business, 40: 157-202.

Conea, A.M. (2011). The requirements for protection of the community design. Lex et Scientiae International Journal, 18(1): 129143.

Cremers, K. et al. (2017). Patent litigation in Europe. European Journal of Law and Economics, 44: 1-44.

Davies, G. (2012). The $50^{\text {th }}$ anniversary of the Rome Convention for the Protection of Performers, Producers of Phonographs and Broadcasting Organizations: Reflections on the background and importance of the Convention. Queen Mary Journal of Intellectual Property: 206-224. Available: https://www.elgaronline.com/view/journajip/2-3/qmjip.2012.03.01.xml

Davis, J. (2020). "Fack Ju G?hie": Or when is a trade mark offensive? The Cambridge Law Journal, 79: 234-237.

Fanelli, L. (2011). A fashion forward approach to design protection. St. John's Law Review, 85: 285-312.

Gallagher, W.T. (2012). Trademark and copyright enforcement in the shadow of IP law. Santa Clara Computer and High Technology Law Journal, 28: 453-497. 
https://ijbssrnet.com/index.php/ijbssr DOI: 10.47742/ijbssr.v2n1p1

Ganim, N.A. (2019-2020). Is software a product? A comparative study of EU and US law. Master's Degree Programme Law and Technology (Tilburg University). Available: http://arno.uvt.nl/show.cgi?fid=149658

Graneris, A. (2018). Protection of design patents in China and comparison with European Union law: How foreign companies can protect their design patents in China. Beijing Law Review, 10(1): 212-238.

Heneghan, K. (2015). EU-level protection of designs? The registered community design. IEEE Consumer Electronics Magazine, 5(1): 129-132.

Huang, W., \& Li, X. (2019). The e-commerce law of the People's Republic of China: E-commerce platform operators liability for third-party patent infringement. Computer Law and Security Review, 35(6). Available: https://www.sciencedirect.com/science/article/pii/S0267364919301414

Hughes, J. (2012). Photograph as art, photograph as database. Harvard Journal of Law and Technology, 25: 327-413.

Jobe. C.K. (1981). The model uniform product liability act- Basic standards of responsibility for manufacturers. Journal of Air Law and Commerce, 46(2): 389-417.

Kasperkiewicz, J. (2017). Fashion design protection in the European Union: Unregistered community design. Fordham Intellectual Property, Media \& Entertainment Law Journal (February 22, 2017). Available: https://perma.cc/F3WD-XC45

Kelemen, R.D. (2016). The Court of Justice of the European Union in the twenty-first century. Law and Contemporary Problems, 79: 117-140.

Kennedy, K. (2014). What is heirloom jewelry? Days Jewelers (February 18, 2014). Available: https://www.daysjewelers.com/blog/heirloom-jewelry/what-is-heirloom-jewelry

Kielar, S.E. (2020). Allowing multiple claims in design patents. Buffalo Law Review, 68: 1169-1213.

Krikke, J., \& Klopper, J. (2020). EU: Concept of infringement of intellectual property rights. Computer Law Review International, 21(2): 56-60.

Kropiwnicka, M. (2019). The protection of unregistered designs in EU law. Eastern European Journal of Transnational Relations, 3(1): 81-92.

Kuijper, P.J. (2018). The Court of Justice of the European Justice. In R. Howse, H. Ruiz-Fabri, G. Ulfstein, \& M.Q. Zang, The legitimacy of international trade courts and tribunals (pp. 70-137). Oxford, U.K.: Oxford University Press.

Lannetti, D.W. (2000). Toward a revised definition of "product" under the Restatement (Third) of torts: Products liability. Torts and Insurance Law Journal, 35: 845-887.

Leitch, V. (2018). Validity of registered community designs: Novelty and prior disclosure-snappy guidance from Crocs $v$. EUIPO and Gifi Diffusion. Journal of Intellectual Property and Practice, 13(11): 854-856.

Lince, T. (2018). Christian Archambeau officially appointed executive director of EU Intellectual Property Office. World Trademark Review (October 1, 2018). Available: https://www.lexology.com/library/detail.aspx?g=71653091-08bd-43ca-96a0-881b4320fce1 Ling, P. (2019). There is no substitute for a Porsche- Except another Porsche? The IPKitten (June 16, 2019). Available: https://ipkitten.blogspot.com/2019/06/there-is-no-substitute-for-porsche.html

Martinez, J. (2019). An expansion of copyright protection. University of San Francisco Law Review, 53: 369-391.

Miniotas, M. (2005). Novelty and individual character in the community design law. LUP Student Papers(Lund University). Available: https://lup.lub.se/student-papers/search/publication/1554965

Monseau, S. (2011). European design rights: A model for the protection of all designers from piracy. American Business Law Journal, 48(1): 27-76.

Morris, P.S. (2019). Private intellectual property regulation in public international law. University of California Davis Journal of International Law and Policy, 26:147-190.

Mudrytska, K. (2020). Specificity of proof in cases of infringement of intellectual property rights on sites on the Internet. ScienceRise (5): 103-110.

Nieto, J. et al. (2015). European Patent Office (EPO): Facts, figures and services for researchers and inventors. $3^{\text {rd }}$ International Conference on Electric Power Equipment- Switching Technology (ICEPE): 193-197. Available: DOI: 10.1109/ICEPEST.2015.7368435

Ramirez-Montes, C.J. (2020). The elusive distinctiveness of trade dress in EU trademark law. Emory International Law Review, 34: 277-365. 
Ricketson, S., \& Ginsburg, J.C. (2006). International copyright and neighboring rights: The Berne Convention and beyond. Oxford, U.K.: Oxford University Press.

Saw, C.L. (2019). Implications of reposting copyright material online and Svensson distinguished in CJEU judgment: Land Nordrhein-Westfalen v. Dirk Renckhoff. Singapore Academy of Law Journal, 30: 1126-1132.

Sciaudone, R. (2012). Community design: Prior in time, stronger in right. Journal of Intellectual Property Law \& Practice, 7(6): 401-403.

Sfarlog, T-V. (2020). Critical appraisal of the recent case-law of the European Union Intellectual Property Office (EUIPO). International Conference, Knowledge Based Organization, 26(2):228-231. Available: https://content.sciendo.com/configurable/contentpage/journals $\$ 002 \mathrm{fkbo} \$ 002 \mathrm{f} 2 \$ 002$ farticle-p228.xml

Silbey, J. (2019). Justifying copyright in the age of digital reproduction: The case of photographers. University of California Irvine Law Review, 9: 405-454.

Silbey, J., Subotnik, E.E., \& DiCola, P. (2019). Existential copyright and professional photography. Notre Dame Law Review, 95 : 263-325.

Thinn Oo, K.T. (2019). Protection of product designs: Trade dress. Journal of the Myanmar Academy of Arts and Sciences, 17(8): 257-276.

Tse, T. (2016). Coco way before Chanel: Protecting independent fashion designers' intellectual property against fast-fashion retailers. Catholic University Journal of Law and Technology, 24: 401-431.

Woods, M. \& Monroig, M. ((2015). Fashion design and copyright in the US and EU. World Intellectual Property Organization (November 17, 2015). Available: http://www.wipo.int/edocs/mdocs/mdocs/en/wipo_ipr_ge_15/wipo_ipr_ge_15_t2.pdf

Wu, X. (2019). Discussion on the liability of patent indirect infringement on the network trading platform. Advances in Social Sciences, Education and Humanities Research,329: 1870-1874 (4 $4^{\text {th }}$ International Conference on Contemporary Education, Social Sciences and Humanities). Available: https://www.atlantis-press.com/proceedings/iccessh-19/125912160

Yu, P.K. (2020).TRIPS and its contents. Idea (Law Review of the Franklin Pierce Center for Intellectual Property), 60: 149-234.

Zelechowski, L. (2016). Damages for infringement of intellectual property rights: Current developments in EU case law. M. Vivant (ed.). In European case law on infringements of intellectual property rights (pp. 211-226). Brussels, Belgium: Bruylant Editions.

Zhang, A.H. (2016). The faceless court. University of Pennsylvania Journal of International Law, 38: 71-135.

Zhang, M. (2018). Online photos can’t be used without permission, EU court rules. Petapixel.com (August 8, 2018). Available: https://petapixel.com/2018/08/08/online-photos-cant-be-used-without-permission-eu-court-rules/

Zongiu, G. (2015). Alibaba group, cited in Huang, Z. (2015). The Chinese government has erased a damning report on Alibaba, but you can read it here. Quartz (January 29, 2015). Available: https://qz.com/335675-the-chinese-government-has-erased-a-damningreport-on-alibaba-but-you-can-read-it-here/

\section{WEB SITES}

Association of Corporate Counsel (2019). 2019 global legal department benchmarking report (In partnership with Major, Lindsey, \& Africa). Available: https://www.acc.com/sites/default/files/2019-07/ACC_Benchmark_071919_Full.pdf(last accessed December 17, 2020).

Bardehle Pagenberg (2020). Design protection in Europe. Available: https://www.bardehle.com/ip-newsknowledge/publikation/detail/ipnews/info/design-protection-in-europe.html (last accessed December 13, 2020).

EUIPO (2020a). The European Observatory. Available:

https://euipo.europa.eu/ohimportal/web/observatory/home?utm_content=bufferc159f\&utm_medium=social\&utm_source=twitter.c om\&utm_campaign=buffer (last accessed December 14, 2020).

EUIPO (2020b). Orphan Works data base. Available: https://euipo.europa.eu/ohimportal/orphan-works-database (last accessed December 13, 2020).

EUIPO (2020c). Disputes. Available: https://euipo.europa.eu/ohimportal/disputes (last accessed December 13, 2020).

EUIPO (2020d). FAQs on copyright. Available: https://euipo.europa.eu/ohimportal/web/observatory/faqs-on-copyright (last accessed December 13, 2020).

European Patent Office (2020). A hub for innovation and enhancing Europe's competiveness. Available: https://www.epo.org/newsevents/press/background/epo.html (last accessed December 18, 2020).

European Union. (2020). European IPR Helpdesk. Fact sheet: Copyright essentials. Available: http://iprhelpdesk.eu/Fact-SheetCopyright-Essentials (last accessed December 13, 2020). 
https://ijbssrnet.com/index.php/ijbssr DOI: $10.47742 /$ iibssr.v2n1p1

Patworx (2020). International design patent. Available: https://www.patworx.net/en/international-design-patent (last accessed December 15, 2020).

Photo Claim. (2020). Photography copyright in Europe. Available: https://photoclaim.com/en/photography-copyright-in-europe/ (last accessed December 13, 2020).

Schmitt \& Orlov (2019). China made the first steps in protecting designs under the Hague Agreement (September 12, 2019). Available: https://www.lexology.com/library/detail.aspx?g=98a8a03d-12b2-4eaa-90a9-cf264da2a7c1 (last accessed December 17, 2020).

Tysver Beck Evans (2020). Patent requirements. Available: https://www.bitlaw.com/patent/requirements.html (last accessed December 13, 2020).

Up Counsel (2020). Design patent infringement: Everything you need to know. Available: https://www.upcounsel.com/designpatent-infringement (last accessed December 13, 2020).

WIPO (2013). Summaries of conventions, treaties and agreements administered by WIPO. Available: https://www.wipo.int/publications/en/details.jsp?id=3857\&plang=EN (last accessed December 18, 2020).

WIPO (2020a). Summary of the Hague Agreement Concerning the International Registration of Industrial Designs (1925), as amended by the 1999 Act and the 1960 Act. Available: https://www.wipo.int/treaties/en/registration/hague/summary_hague.html (last accessed December 16, 2020).

WIPO (2020b). About the Locarno Classification. Available: https://www.wipo.int/classifications/locarno/en/preface.html (last accessed December 13, 2020).

INSTITUTIONAL WEBSITES

Court of Justice of the European Union (2020). Available: https://curia.europa.eu/jcms/jcms/j_6/en/ (last accessed December 18, 2020).

European Patent Office (2020). Available: https://www.epo.org/ (last accessed December 18, 2020).

WIPO (2020): https://www.epo.org/ (last accessed December 18, 2020).

\section{CASES}

Land Nordrhein-Westfalen v. Dirk Renckoff (2018). Case c-161-17. Available:

https://eur-lex.europa.eu/legal-content/EN/TXT/?uri=CELEX\%3A62017CJ0161

Woodhouse UK PLC v. Architectural Lighting Systems. (2006). EPCC 25, [2006] RPC 1, [2006] ECDR 11. Available: https://academic.oup.com/rpc/article/123/1/1/1592166 